bers as they have been this year. He also adds that he has not seen them until this winter since they appeared in 1872 or 1873 .

My series of specimens from Yemassee embraces twenty-nine examples, representing every stage of variation.

Since writing the foregoing I visited Yemassee again, and on April I, I887, one of my collectors shot thirteen specimens; on April 2 I shot a single specimen; again on April 4 my collector brought me ten specimens. The number of specimens killed in April was about thirty, as several were thrown away being in poor plumage.

I visited Yemassee again in May and found the Crossbills still there, but not in such numbers as in April. My collector brought me a female on May 6, and a male on May i9. These two specimens were the only ones taken in May. The Crossbills were seen for the last time on May 22, but I am under the impression that some of them remained until the first of June, when they all left for their breeding grounds in the mountains:

I am positive that none of the Crossbills bred at Yemassee, as the ovaries in the females were about the size of No. Io, shot in April and May and all the previous months.

The Crossbills were not confined to Yemassee and vicinity alone, for they were shot at Hampton C. H., and at Brunson, in Hampton County. My opinion is that they were scattered all over Hampton County.

The departure of the Crossbills late in May to their breeding grounds may prove that the Crossbills which breed in the mountains of North Carolina do not breed until the summer, and, curiously enough, in this respect are very different from the Crossbills of the North, which breed in the winter and early spring months.

\title{
BIRDS OF TOM GREEN AND CONCHO COUNTIES, TEXAS.
}

\author{
BY WILLIAM LLOYD.
}

(Concluded from p. 193.)

133. Cyanocitta cristata. Blue Jay. - Abundant in Zavalla and Dimmit Counties, near Eagle Pass, on the Rio Grande. Its limit to the 
west seems to be near the mouth of the Main Concho, where it is tolerably common. Seen in northern and western Concho County only in the fall. Does not occur in Tom Green County, where it is replaced by the next species.

I34. Aphelocoma woodhousei. Woodhouse's JAY. - Resident wherever there is shin-oak, at the heads of nearly all the creeks. Tolerably common. Nest with three eggs found April 19, $\mathrm{IS}_{5}$, on Spring Creek, in low underbrush; and another, same date and position of nest, with three young.

I35. Corvus corax sinuatus. American RAven. - Occasional visitor at all times of the yeár, both in Concho and Tom Green Counties. Nest with six eggs found May ${ }_{5}, \mathrm{I}_{\mathrm{S}} 8_{3}$, in mesquit.

i36. Corvus cryptoleucus. White-Necked Raven.-Resident; abundant at times. The bulk retire in fall in large flocks down the Pecos and Devil's Rivers, where they winter by thousands. A nest with six eggs found May I9, I882, in a low hackberry; another nest, partly finished, was found May $\mathbf{I}_{3}, \mathbf{I} 88_{3}$, and a third, with three eggs, May $5, I_{5} 8_{5}$, in low mesquits.

137. Corvus americanus. American Crow. - Abundant in summer. Breeds in colonies, in the eastern part of Concho County, the beginning of May.

I38. Molothrus ater. CowbIRD.-Spring and fall, in migration.

I39. Molothrus ater obscurus. Dwarf Cowbird. - Abundant in summer. Lays in the nests of Vireos, Nonpariels, Orchard Orioles, etc.

I40. Xanthocephalus xanthocephalus. Yellow-HeAded BlackBird. - Abundant spring and fall migrant. A flock seen June 25, I8S6, in Pecos County.

I4I. Agelaius phœniceus. Red-winged Blackbird. - Abundant spring and fall migrant. Wintered the present year in large numbers in Concho County, for the first time (except stragglers) - a fact attributable to the greater area in cultivation in this locality, this area increasing year by year and exercising an appreciable effect on the bird life. The males keep in separate flocks with the young males; a few of the latter, however, are found with the females.

I42. Sturnella magna. MEAdow LARK. - Abundant during migrations.

143. Sturnella magna neglecta. Western Meadow Lark. - Resident. Especially abundant in fall and winter. Nest generally in a rabbit form. In $\mathrm{ISS}_{2}$ nests were found March 27, two eggs, and April I5, five eggs; in $188_{3}$, April 24, five eggs; in ${ }_{1} 88_{5}$, May Io, five young.

I44. Icterus spurius. ORCHARD ORIOLE.-Abundant in summer. The males arrive about April 13, followed by the females four or five days later. Common on April 2r. The males depart very early; none noted for four years after August 5, while the females and young are noted from September 4 to I $5_{5}$. Breeds in hanging nests on mesquits. Earliest clutches May I9 (four eggs), and June I (five eggs).

I45. Icterus bullocki. Bullock's ORiole.-Tolerably common, espec- 
ially on the main streams. I noted a male, evidently a straggler, April 6. The ordinary date of arrival is April I $_{5}$ to 20 , the birds becoming common about April 24. The females are very retiring. The males are seen with the family as late as September 30 . Breeds on the top branches of the mesquit. Nest similar to that of the last; both elaborately woven out of horse-hair and lined with wool. A sprig of mistletoe is generally woven into one side of the nest. Clutches found May ${ }_{15}$, two; May I6, six; May 28 , five, and June $I$, six. In all except two the clutch was six, the others having respectively five and four.

146. Scolecophagus cyanocephalus. BREwer's BLACKBIRD. - Fall migrant, wintering occasionally in Tom Green County. Abundant in winter further south, in the Neuces Cañon.

I47. Quiscalus quiscula æneus. Bronzed Grackle. - Abundant spring and fall migrant. Some specimens can hardly be separated from eastern ones. A few winter in Tom Green County.

I48. Carpodacus purpureus. Purple Finch.-One specimen, shot by Mr. Loomis, October 20, I886.

I49. Spinus tristis. American Goldfinch. - Common in fall, arriving middle of August.

i5o. Spinus psaltria. Arkansas "Goldfinch. - Rare fall migrant. Taken on South Concho, end of August.

I5I. Rhyncophanes mccownii. McCown's Longspur. - Abundant winter visitor. Arrives November 5, leaves in March.

152. Poocætes gramineus. Vesper SPARrow. - Tolerably common in fall, in eastern part of Concho County.

153. Poocætes gramineus confinis. Western Vesper Sparrow. Resident. Tolerably common in winter in old cane fields. Nearly all leave in spring, but are probably common in the western half of Tom Green County. Nest found on the Plains May 16, I885, with four eggs. In fall, in flocks on the Plains; in winter in pairs.

i54. Ammodramus sandwichensis alaudinus. Western Savanna Sparrow. - Resident. Tolerably common. No nest identified with certainty. Found near cultivated fields, and in marshy or boggy land.

155. Ammodramus bairdii. Baird's SPARRow. - Rare fall visitor, shot in cane fields. Winters abundantly west of Tom Green County.

I56. Ammodramus savannarum perpallidus. Western GrasshopPer Sparrow. - Resident. Tolerably common in Concho County in fall; at other times rare. Two nests found at the edge of the Plains in Tom Green County; one May 17, I885, with four eggs; the other May 22, $188_{5}$, four eggs.

I57. Chondestes grammacus strigatus. Western Lark Finch. Abundant summer visitor. Arrives in flocks March 24, earliest noted; departs October 8. Migrants pass through from October 25 to November 5. Breeds April 26 to June 5. Raises two broods. Clutch 4-5. Nest in bushes or on the ground.

I58. Zonotrichia querula. Harris's Sparrow.-Rare fall migrant in eastern Concho County. 
I59. Zonotrichia leucophrys. White-crowned Sparrow. - Abundant winter visitor, in Concho County. Arrives the middle of October and remains until May. Frequently found in immense flocks. In song all winter on sunny days.

I6o. Zonotrichia intermedia. Intermediate Sparrow. - Common winter visitor in Tom Green County; tolerably common in Concho County. Arrives same time as the last in small flocks of six to twelve.

I6r. Spizella socialis. Chipping SPArRow.-Tolerably common in small flocks of four to six in Concho County, in fall and early winter. A few remain until spring.

i62. Spizella socialis arizonæ. Western Chipping Sparrow. Resident in Tom Green County. Tolerably common in winter; rare in summer. Breeds. A nest, the only one met with, found on Spring Creek, May $8, \mathrm{I}_{8} 8_{5}$, in a low chapparal bush, contained four eggs fully incubated.

I63. Spizella pallida. Clay-COlored Sparrow.-Abundant in spring and fall.

164. Spizella breweri. Brewer's SPARrow. - Tolerably common in Tom Green County in fall. Winters in abundance in Pecos County.

165. Spizella pusilla. Field SPARrow. - Tolerably common in small flocks of from four to five in fall; rare in winter. Not noted in Tom Green County.

I66. Spizella pusilla arenacea. TEXAS Field SPARrow.-Rare in fall and winter in Tom Green and Concho Counties.

I67. Junco hyemalis. Slate-Colored Junco. - Common in winter. Arrives middle of October and remains until end of March.

I68. Junco hyemalis oregonus. Oregon Junco.-Tolerably common in Tom Green County in winter. Occurs on the Main Concho in Concho County, in limited numbers.

r69. Amphispiza bilineata. Black-throated Sparrow. - Common resident This species has extended east within the last six years to the Colorado River. Breeds, raising two broods. Nests in cat-claw or chapparal bushes. Nests found May 6, May 13, June i2, July I3. The eggs have a bluish tinge until blown, when they become pure white. A voluable and pleasing songster. Sings about noon every day after middle of March.

I70. Peucæa æstivalis bachmanii. Bachman's Sparrow. - Summer visitor in eastern Concho County. Nests found May 20 to June I; eggs invariably four.

i7r. Peucæa cassini. Cassins Sparrow.-Common summer visitor in Tom Green County, and tolerably common in Concho County in fall. Breeds on the Plains at the head of Spring and Dove Creeks. Four nests, found May 25, 27, and 29, had five eggs in each. Nests in low bushes, not higher than one foot from the ground, or in tufts of grass. A remarkable songster during the breeding season. Like the last species, it ascends in spirals about twenty feet, singing, the apex of its flight marking the termination of its song. Alights often on the same bush and again soars. 
172. Melospiza fasciata. Song Sparrow. - Tolerably common in winter in Tom Green and Concho Counties.

I73. Melospiza lincolni. Lincoln's Sparrow. - Tolerably common during spring and fall migrations from the Pecos east to Colorado. Lingers in cane fields until Christmas.

I74. Melospiza georgiana. Swamp Sparrow.-Rare in spring migration in Concho County. Winters on the edge of the Plains at the head of the South Concho (Tom Green County).

175. Pipilo erythrophthalmus. TowheE.-Occasional winter visitor in Tom Green and Concho Counties. Two were shot in January, I884.

I76. Pipilo maculatus arcticus. Arctic Towhee. - Winter visitor. Tolerably common in suitable places. Arrives October 8, and remains until the first week in May.

177. Pipilo fuscus mesoleucus. Cañon Towhee.-Resident and tolerably common in Tom Green County. Mr. Loomis shot three in the fall of I886 in Eastern Concho County. Nest with three incubated eggs, in fork of small live oak in Tom Green County, found April 12, $188_{5}$. Nests found further west contained five eggs; so three is an exception. The A. O. U. 'Code and Check-List' gives rits habitat as "Valley of Upper Rio Grande"; it should now include Valley of the Conchos to Colorado River. Heard its song only once, August I2, ISS4.

i78. Pipilo chlorurus. Green-tailed Towhee. - This bird must be spreading east, as I see it as far east as the head draws of the Middle Concho. Common on the east side of Pecos River. Probably breeds.

I79. Cardinalis cardinalis. CARdinal. - Abundant resident. Very small flocks of this species are found in the river bottoms in winter. None seen west of the head draws of the creeks that rise in the Plains. Raises two broods. Earliest clutch found April 7; latest June 30.

iSo. Pyrrhuloxia sinuata. Texan Cardinal. - Accidental visitor in Tom Green County. One was shot in May, IS85. I hear they occur in winter in the eastern part of Concho County, but have not seen them.

iSi. Habia melanocephala. Black-headed Grosbeak. - Rare sum. mer visitor; probably breeds. Shot a male August 5, ISS6, in Concho County. No nests found. This supplements Mr. Geo. H. Ragsdale's record of one observed in spring at Colorado City, on the Texas and Pacific Railroad.

I82. Guiraca cærulea. Blue Grosbenk.-Tolerably common migrant in fall, from the Pecos River to the Colorado River; breeds abundantly further west.

$\mathrm{IS}_{3}$. Passerina cyanea. Indigo Bunting.-Rare fall migrant in Tom Green County. One was observed June $5,188_{3}$, in Concho County.

i84. Passerina ciris. Painted Bunting.-Common summer visitor. Raises two broods. Nests found from May 12 to July I4. Clutch 4-5. Builds generally in hackberry, but often in cat-claw and chapparal. The males arrive April 27 to 30 in small flocks. One female recorded April i 9 , I885, but for two other years the females came after the males. A well known and delightful songster. The young female does not assume full plumage until the second year. 
185. Spiza americana. Black-throated Bunting. - Abundant spring and fall migrant. Appears in wandering flocks through the summer, but I know of no instance of its breeding. This is another bird, which, like the Black-throated Sparrow, six years ago scarcely known, is now abundant.

I86. Calamospiza melanocorys. LARK Bunting. - Abundant in winter in immense flocks. Arrives the beginning of November and stays until the first week in March. Frequents grain fields.

i87. Piranga ludoviciana. Louisiana Tanager. -- A male was shot by $\mathrm{Mr}$. Cope in the spring of 1886 in South Concho.

i88. Piranga erythromelas. Scarlet Tanager.-Accidental in Tom Green County in the spring of 1885 . Described as being tolerably common in spring migration, in eastern Concho County.

i89. Piranga rubra. Summer Tanager. - Tolerably common summer visitant. Males arrive April 6; the females April 24. Breeds. No nest found before June 3 , and June 6 . Nest, like the Cardinal's, generally made on a branch of a low pecan on the main streams; never away from the water. Departs September Io.

19o. Progne subis. Purple Martin.-Common summer visitant in suitable places. Breeds about the towns in colonies. Arrives the last of February; departs November I.

191. Petrochelidon lunifrons. Cliff Swallow. - Common summer visitant. Arrives early in April. I believe they raise two broods. Sometimes breed in barns. First nest, found under a bluff, May 4, with three eggs; another July 20, with four fresh eggs.

192. Chelidon erythrogaster. BarN Swallow. - Common summer visitant. Breeds about settlements, raising two broods. Nest with four eggs found August I, I883, at Paint Rock, Concho County.

193. Tachycineta thalassina. Violet-green Swallow. - Fall migrant in Concho County; observed and taken September I, I885; seen October I, I886. Not recorded in Tom Green County.

194. Clivicola riparia. Bank Swallow. - Rare fall migrant in Concho County.

Swallows are numerous in fall (September to end of October), but as they often fly at great heights, it is impossible to procure or identify them.

195. Ampelis cedrorum. Cedar Waxwing.-Abundant in fall and again in spring. A few winter, feeding on the mistletoe berries - about the only berry left after January I. Winter all over Western Texas. One shot in the fall of I 886 had orange tips to the tail-feathers.

i96. Lanius ludovicianus excubitorides. White-rumped Shrike. Abundant resident. Nests found from April 27 to May 21. Clutch six (in rare instances five). I first heard its song in September, I884, and could hardly imagine the vocalist was a Shrike. Its song is a very pleasing one, in a minor key, as if practising. Since that date $I$ have heard it frequently in the fall, from September to the middle of November. It is also an accomplished mimic, imitating Sturnella magna neglecta perfect- 
1y. It lives on grasshoppers when it can procure them, and in winter, when the weather is severe, takes to carrion. I found one in January, I884, so gorged from feeding on a dead sheep that it could not fly. In the Davis Mountains it lives in winter on large coleoptera. In spring it occasionally kills birds. I have seen Spizella socialis arizonce, Vireo belli, Polioptila carulea, and others, amongst its victims, and in summer it has a fancy for nestlings. It is usually very tame.

197. Vireo olivaceus. RED-EYED VIREO. - Abundant summer visitor in Tom Green County. Only noted during the fall migration in Concho County. Arrives April II, after the Black-capped Vireo and on the same day as Bell's. Comes in pairs; nest found May 6, I885, with six eggs. A pleasing songster.

198. Vireo gilvus. Warbling Vireo. - Rare spring migrant. Not noted in Concho County.

199. Vireo atricapillus. Black-CAPPED Vireo. - Tolerably common in Concho County, during the fall migration. Breeds in two localities in Tom Green County. The males arrive April 6, the females the 7 th. Though silent on arrival, by the roth the famous song of the male is heard, and is continued through the summer until the middle of August. The song is loud, clear, and very musical, and the singer generally selects some blasted pecan stump for the site of his vocal efforts. The female has also a song, sweet, but not particularly noticeable. This joyous habit led me to look for the vocalist, April 28, 1885 , and I soon discovered him sitting on a nest just completed. I found three other nests in the same way. The nest was always in some low tree at the edge of thick shrubbery, and is at once distinguishable from that of Bell's Vireo, which breeds in the same vicinity, in that the latter is lined with wool, while the Black-cap's is not. The eggs are pale white, as stated by Dr. Coues and others, and a full clutch is 4-5. Leaves Tom Green County altogether from August 20 to 25 , but lingers in Concho County until the last week in September. This record fills part of the gap between Mr. Nathan C. Brown's record at Boerne, Mr. Ragsdale's in Cook County, and Col. Goss's in Kansas.

200. Vireo noveboracensis. White-eyed Vireo. - Fall migrant. Two secured in Concho County, October, I8S6. The eyes were pink in the specimens shot.

20I. Vireo belli. Bell's Vireo. - Abundant summer visitant. Arrives about the same day as the Red-eyed Vireo, and stays until the middle of September. Raises two broods. Nests found May 6 to July 6 . Average clutch, six. One nest found May 8, 1884, had eight eggs. A tireless songster, but there are so many fine singers in this district that it does not attract much attention.

202. Mniotilta varia. Black-AND-White Warbler.-Common during migrations. Arrives April I2-I3; departs September I2-I4. I believe some breed, as I have seen them in June, but as they frequent the main stream, it would be only by chance that their nest could be found.

203. Helminthophila ruficapilla gutturalis. Calaveras Warbler. This western representative of the Nashville Warbler is abundant in fall, 
with the Orange-crowned; seen on the Plains with Bell's Vireo, Blue Grosbeak, etc., in October, $\mathrm{I} 88_{5}$.

204. Helminthophila celata. Orange-crowned Warbler. - Abundant in the fall migration (may be var. lutescens).

205. Helminthophila peregrina. Tennessee Warbler. - Early fall migrant in Tom Green County. Tolerably common,

206. Dendroica æstiva. Yellow Warbler. - More abundant than all the other Warblers together in spring and fall. A few may breed, as I have seen them during all the summer months.

207. Dendroica coronata. Myrtle Warbler. - Spring migrant. Tolerably common, May i3.

208. Dendroica auduboni. Audubon's Warbler. - Tolerably common spring and fall migrant. Arrives in spring, May I3. In fall I saw it in crossing the Plains the first week in October, and shot two from a flock as late as October 20, I886, in Concho County.

209. Dendroica cærulea. Cerulean Warbler.-Saw small flocks of five to eight in crossing the Plains, the middle of October, 1885 .

2 Io. Dendroica chrysoparia. Golden-cheeked Warbler. - One was shot in a hackberry in April, IS87. Its stomach contained winged (female) ants.

2i i. Dendroica virens. Black-throated Green Warbler. - Common fall migrant, from August I to September 20.

212. Dendroica townsendi. Townsend's Warbler. - Rare migrant in spring and fall. Arrives May 8. Undoubtedly breeds in Tom Green County, near the plains, in a dense swampy undergrowth full of springs, about five miles in circumference. Seen May $3^{I}$ and July $3 \mathrm{I}$, in thickets some two miles from the river, along which it migrates. In fall seen from September I to I2, on Lipan Creek (Euterpe on map), where one was killed on the Ioth by Mr. Loomis. Shot September 5 , in Tom Green County. Mr. Henshaw, in 'The Auk,' speaks of it as occurring on the Upper Pecos. The A. O. U. habitat is east as far as Western Colorado and south into Mexico; hence this record considerably extends the range of this species to the south and west.

213. Seiurus aurocapillus. Oven-BIRD.-Overlooked until September I0, I8S6, when I shot one specimen and saw another in Concho County.

214. Geothlypis philadelphia. Mourning Warbler. - Tolerably common in fall migration in Concho County. None seen after September $\mathrm{I}$. Feeds on ants. Mr. Sennett's record is the only other notice I can find of this species in Texas.

215. Geothlypis macgillivrayi. Macgillivray's Warbler. - Abundant from Castle Hill to Pecos River. Probably breeds.

216. Geothlypis trichas occidentalis. Western Yellow-throat. Abundant spring and fall migrant.

217. Icteria virens. Yellow-breasted Chat. - Tolerably common during the spring migrations.

218. Icteria virens longicauda. Long-tailed Chat.-Abundant summer visitor, especially in dense undergrowth. Very numerous in the 
swamps above mentioned, where I believe Townsend's Warbler breeds. Arrives in pairs the middle of April; all are mated by the end of April. They have a peculiar breeding cry,-like the sound of a gate swinging on rusty hinges, easily and successfully imitated to procure specimens. I found its nest May $6, \mathrm{I} 88_{5}$, at the edge of a thicket in a low bush; clutch four. All summer it is a most admirable mimic, and frequently throws such ventriloquial powers into its voice as to make the vocalist seem anywhere but where he is. Migrates leisurely, and is not finally lost sight of until October I.

2I9. Sylvania pusilla. Wilson's Warbler. - Abundant spring and fall migrant. In fall every storm brings a fresh lot of this Warbler, the Golden, Nashville, Orange-crowned, and others. They linger often only a few hours, and there is a lull in the migration until the next storm. Abundant all over Western Texas from April 2 to May 15, and from September 3 to 30 .

220. Sylvania canadensis. Canadian Warbler.-One was shot from a flock of six, about the end of August, I885, in Concho County.

22I. Setophaga ruticilla. Redstart. - Abundant during the fall migration from August 3 I to September Io, in Concho County.

222. Anthus pensilvanicus. American Pipit. - Common in fall migration; less common in spring.

223. Anthus spragueii. Sprague's Pipit.-One was shot in January, I885, in Tom Green County, at the edge of the Plains. A small flock was seen in Concho County, October 15, 1886.

224. Oroscoptes montanus. SAge Thrasher. - Tolerably common resident in Tom Green County. Winters in Concho County, as far east at least as Colorado. No eggs found but I have seen scores of nests.

225. Mimus polyglottus. Mockingbird. - Abundant resident. Locally migratory in winter. Raises two broods, perhaps three. Nests found from April i5 to July i6. Clutch 4-5. Sings all through the winter, and often at night. A great scold, and in winter has a special enmity to Flickers.

226. Galeoscoptes carolinensis. CAtbird. - Occasional migrant in spring and fall, in the eastern part of Concho County.

227. Campylorhynchus brunneicapillus. Cactus Wren.-A summer bird, and probably resident in Tom Green County on the Plains. Seen migrating south with other birds September 30, I885. Abundant in July, on the line of the Texas and Pacific Railroad. No nests found within our limits, but just outside (west) one was found May 6, containing three young, and on May 16 one with six eggs, in a palma cactus.

228. Salpinctes obsoletus. Rock Wren.-Common winter visitor, from October 7 to May I. Breeds further west.

229. Thryothorus ludovicianus. Carolina Wren.-Rare winter visitant; seen only on Spring Creek, in Tom Green County. Probably breeds, as a pair were noted in a thicket, May $6, \mathrm{I} 88_{5}$.

230. Thryothorus bewickii bairdii. BaIRD's Wren. - Resident; common. A fine singer from early spring till fall. Breeds anywhere; in old 
coat sleeves, behind mirrors, in piles of sacks, in old posts. Raises two broods; eggs 4 to 6 . Nests April 15 to June 5 .

231. Troglodytes aëdon parkmanii. Parkman's Wren. - Very common in the fall in Concho County.

232. Cistothorus palustris. Long-billed Marsh Wren. - Spring migrant, in both counties. Rare.

233. Certhia familiaris americana. Brown Creeper. - Tolerably common winter visitor. Arrives October I5.

234. Sitta carolinensis. White-Breasted Nuthatch. - Resident. Rare. Shot in June and January. Found in both counties. No nests known.

235. Parus atricristatus. Black-Crested Titmouse.-Resident. Tolerably common. Breeds in old Woodpecker holes. Nest found April I5, I885, and two others April I8 and 20. This is another species that is spreading eastward. Four years ago they were rarely found except on the main river. Now each creek has a family or two, as far east as the Colorado River. I have found this the prevailing species from here to El Paso.

236. Parus atricapillus. Chickadee. - One taken during the spring migration in eastern Concho County.

237. Parus carolinensis. Carolina Chickadee. - One taken during spring migration in eastern Concho County. A pair found wintering on the river in $\mathbf{I} 886$.

238. Regulus satrapa. Golden-Crowned Kinglet.-Tolerably com mon during the fall migration. A few winter in Concho County.

239. Regulus calendula. Ruby-CROWNed Kinglet.-Abundant from October I to April io.

240. Polioptila cærulea. Blue-gray Gnatcatcher. - Abundant summer visitant. Arrives in pairs March $\mathbf{r}_{3}$; common March 24. Last seen in 1884 , October 5 ; in 1886 , October 8 . No eggs found, but nests with young ( 5 each) May I and 12 .

24I. Turdus ustulatus swainsoni. Olive-backed Thrush. - Fall migrant. Rare in Tom Green County; not observed in Concho County. 242. Turdus aonalaschkæ. Dwarf Hermit Thrush. - Tolerably common fall migrant. Noted every day from September 20 to October IO; to at least Fort Stockton, crossing the Plains.

243. Turdus aonalaschkæ auduboni. Audubon's Hermit Thrush.Spring migrant. Tolerably common in Tom Green County; rare in winter in Concho County. Noted for the first time in I886-87.

244. Turdus aonalaschkæ pallasi. Hermit Thrush. - One taken during the spring migration in eastern Concho County.

245. Merula migratoria. American Robin. - Tolerably common in spring and fall. A few winter in the river bottoms and abundantly further south.

246. Merula migratoria propinqua. Western RoBin. - Rare in fall in Concho County. A few winter in Tom Green County. Abundant in winter west of this county. 
247. Sialia sialis. Bluebird.-Resident in portions of Concho County. Very common in spring and fall. They wander considerably after January $\mathrm{I}$, in search of berries, which are very scarce. Associates frequently with the two next. A nest was found in a hole in an old stump in July, 1882, with four eggs. Young in spotted plumage shot throughout August.

248. Sialia mexicana. Western Bluebird. - Rare winter visitant. Shot in flocks of the common Bluebird in Concho County.

249. Sialia arctica. Mountain Bluebird. - Rare until the fall of I886, when it appeared in immense flocks, and was very unwary, feeding with Cedarbirds and other species on the numerous wild berries in October and November. Some of the males were nearly ultramarine; others in the same flock were various shades of blue. None seen since January IO, $\mathrm{ISS}_{7}$.

Addenda. - 250. Rallus elegans. KIng Rail. - One seen in South Concho, in the spring of I886, by Mr. Cope, who tried to catch it with a dog.

25I. Pandion haliaëtus carolinensis. OSPREY. - Several pairs breed on South Brady, according to Mr. Cope.

252. Chordeiles virginianus henryi. Western Nighthawk. - Rare on the Plains; probably breeds.

253. Spizella monticola ochracea. Western Tree Sparrow.-Common in small flocks, winter of I884-85.

Correction.-On page i83, line i6 from bottom, for "about 240 " read 253 .

\section{ADDITIONS TO THE AVI-FAUNA OF BAYOU SARA, LA.}

\section{BY CHARLES WICKLIFFE BECKHAM.}

In the 'Bulletin of the Nuttall Ornithological Club' for July, IS82, I gave an annotated list of the birds of Bayou Sara, Louisiana, the result of five days' work during the month of April of that year. Eighty-six species were enumerated. Since then I have had an opportunity of making further observations at the same place; extending over a much longer period, from April I to April 28 , and am able to add twenty-seven species to the fauna as heretofore given.

The weather during the period mentioned was exceptionally dry, both for the season and the locality, which fact doubtless 


\section{$2 \mathrm{BHL}$ Biodiversity Heritage Library}

Lloyd, William. 1887. "Birds of Tom Green and Concho Counties, Texas

(Concluded)." The Auk 4, 289-299. https://doi.org/10.2307/4067190.

View This Item Online: https://www.biodiversitylibrary.org/item/54094

DOI: https://doi.org/10.2307/4067190

Permalink: https://www.biodiversitylibrary.org/partpdf/88525

\section{Holding Institution}

Smithsonian Libraries

\section{Sponsored by}

Smithsonian

\section{Copyright \& Reuse}

Copyright Status: Public domain. The BHL considers that this work is no longer under copyright protection.

This document was created from content at the Biodiversity Heritage Library, the world's largest open access digital library for biodiversity literature and archives. Visit BHL at https://www.biodiversitylibrary.org. 